\title{
The Deep Coinherence
}

\section{An Attempt to Understand N.F.S. Grundtvig's Holistic Vision}

\author{
WEN Ge
}

This article examines the expression "den dybe Sammenhæng," which Grundtvig used in his writings. As a means of offering a perspective of Grundtvig's worldview, the article proposes that translating the phrase as "the deep coinherence" can open the phrase for fresh interpretations, which allow us to see how it fits into the theological systems of other religious thinkers, such as the Scottish philosopher Sir William Hamilton and the English writer Charles Williams. For Grundtvig the phrase describes the universal spiritual principle that all things exist in essential relationships with the innate concepts of other things. It therefore also functions to describe how Grundtvig understands the relationship between God, humanity, and nature, specifically how human beings can restore their relationship with God's Word in a postlapsarian world. The human-divine relationship continues through the ministries of the Holy Spirit and the Word in living congregations. Christ set the example for human mediation of spirit and nature. ${ }^{1}$

\section{Introduction}

In keeping with his "Mosaic-Christian" anthropology (mosaisk-christelige Anskuelse), ${ }^{2}$ Grundtvig sought to elevate human life through ecclesial re-

${ }^{1}$ This article is a presentation of the results of the $\mathrm{PhD}$ dissertation: The Deep Coinherence: A Chinese Appreciation of N.F.S. Grundtvig's Public Theology, Arts, Aarhus University, 2013.

2 This is Grundtvig's phrase denoting the understanding of human beings according to the Hebrew Bible. 


\section{WEN GE}

form and civic engagement. His goal was to provide space for human mediation between nature and spirit and between nature and God. Often, however, his well-known but puzzling phrase "Human first, then Christian " (Menneske først, Christen saa) is misunderstood by attending to the chronology of syntax - man comes first because he is mentioned first in the sentence - therefore, it is often misinterpreted as announcing a separation between the human and the divine, or between the folkelig (national) and the Christian life. Even today, Danish church leaders and politicians refer to Grundtvig's ideologies to support their different agendas, leaving us to question whether or not there is in fact any coherence between the secular and the Christian uses of Grundtvig's thought. To answer this question, we would do well to identify a fundamental, unifying structure for Grundtvig's thinking about the nature of the relationship between God and man.

This essay proposes that such a unifying structure is revealed through Grundtvig's use of the phrase "den dybe Sammenhæng" (SV 1, 256), which has been translated, accurately, I argue, as "the deep coinherence." Conceived in the terms of Grundtvig's understanding of the relationship between God's Word and human words and connected with modern theological discourse, this structure might be understood as asserting the nature of the relationship between God, humanity, and nature. The word "coinhere" voices key ideas of unity. It first appears in the philosophical writings of a contemporary of Grundtvig's, the British "metaphysician" Sir William Hamilton (1788- 1856), who sought to identify the forces that bring the physical and the metaphysical, the seen and unseen worlds into harmony. Long after Grundtvig first published his notion of the idea in Danish, the English writer and religious thinker Charles Williams (18861945) also used the word "coinherence" to articulate an idea that rested at the centerpiece of his theology. There is no evidence that Hamilton and Grundtvig knew of each other at all; nor is it likely that Williams was aware of Grundtvig's writings. Therefore, it remains to be known whether or not any connection exists in how the three men thought about spiritual unity. However, their employment of the idea of "coinherence" provides useful in thinking about Grundtvig's theology, particularly how, in Grundtvig's thinking, the Fall influences the relationship between God's Word and human words and how individuals might restore that relationship first from the Christian and then the human perspective. 


\section{Grundtvig's Concept of the Deep Coinherence}

Close attention to Grundtvig's writings reveals that he came to use the phrase "den dybe Sammenhang" in the middle of the 1830s. It appears first in his Handbook of World History in 1833, which I will discuss below, then in an unfinished and unpublished manuscript that was originally titled "Oplysning" [Enlightenment] and was part of his intense preoccupation at the time with education. He writes,

A genuine enlightenment extends itself to the whole of human life, shows the deep coinherence between the life of the individual, the nation, and the whole human race, and develops a way of thinking that is desirable for all social relations $(S L, 83)$.

Later in 1837, in the hymn "Hil dig, frelser og forsoner!" (Hail, our reconciling Saviour), Grundtvig again used the phrase "den dybe Sammenhæng," this time to signal a spiritual relationship. Here is the seventh stanza of that hymn:

As for me You once have striven,

May I love life in You given;

May my heart for You alone beat,

So my thoughts alone in You meet,

In whom all things coinhere.

$(L W, 94)$

According to the Dansk-Engelsk Ordbog (1995), "sammenheng" is a noun that literally means "connection," "coherence," or "context." 3 But in the above translations Edward Broadbridge conveys the word's meaning with the verb "coinhere". His decision to change "sammenhæng" to a verb and to translate it as "coinhere" opens the passage up to fresh investigation.

The Oxford English Dictionary locates the first use of the verb "coinhere" in the writings of Sir William Hamilton, who used "coinhere" in his university lectures, which were published posthumously as Lectures on Metaphysics and Logic. In "Lecture VIII: Psychology, Its definition. Ex-

${ }_{3}$ Dansk-Engelsk Ordbog (1995), 707. 


\section{WEN GE}

plication of Terms," Hamilton addresses how humans perceive the world around them. He writes,

The existence of an unknown substance is only an inference we are compelled to make from the existence of known phenomena; and the distinction of the two substances is only inferred from the seeming incompatibility of the two series of phenomena to coinhere in one [substance]. ${ }^{4}$

Important to Hamilton in this passage is how humans can "know" about the unknown, how they can be confident of its existence. He is concerned with the relationship of mind and matter.

Later on, the British writer and theologian Charles Williams (18861945) also adopted the word "coinherence," but, unlike Hamilton, he used it in consideration of the interrelatedness of all things. He wanted to depict the "universal spiritual principle" that "[t]hings exist in essential relationship with another, as innate components of the other," as in the cases of the relationship between "unity of humankind" and "unity of God," St. Mary's conception of Christ, St. Paul's description of a converted Christian's participation in Christ, the relationship between "the natural and spiritual" and "the two natures of Christ (human and divine)." Take the two natures of Christ as an example. Despite their difference, the full humanity and divinity coexist in Christ "without confusion, without change, without division, and without separation" as defined by the Chalcedon Formula of 451. The two natures are fused, but not confused.

While students of Williams' work through the years have complained about the complexity of this concept, I contend that it describes the deep connection and mutual participation of two seemingly different but inseparable components existing in one reality. The two components are also mutually constituent, complementing each other, like divine and human nature coexisting in the one person of Christ with a hypostatic union. N.H. Gregersen also adopts the translation of "sammenhæng" as "coinherence" to describe the mutual in-dwelling of Christ and Christians (Gregersen 2004, 7). When referring to the mutual participation

${ }^{4}$ See William Hamilton, "Lecture VIII"

5 See The Inklings, web.sbu.edu/friedsam/inklings/coinheretance.htm (accessed January 3, 2013). 


\section{The Deep Coinherence}

of "God and the world," Gregersen alters "coinherence" with the phrase "mutual inherence" (Gregersen 2009, 144). Since "coinherence" can cover the meanings of both "coherence" and "inherence," I interpret it to mean not only a coherent connection, but also a mutual participation, coupled with a divine in-dwelling in the human.

The concept relates to Grundtvig's worldview, in which nothing exists in a separated and isolated state. In Volume I of The Handbook of World History, Grundtvig writes:

There is nevertheless a deep coinherence in all things, not just between a man and his mother, as the earth is for him, and between us and the air we breathe. Fundamentally, nothing in the world can be called a 'coincidence' - unless one is a fool! (US VI, 28-29) ${ }^{6}$

Here, Grundtvig makes an ontological claim that the relationship is manifested as both a protological vision and an eschatological reality to be fulfilled.

\section{Grundtvig's Theology of the Word}

To understand the bases for a claim like this one, it is necessary first to think about Grundtvig's theology of the word, especially in terms of the divine-human relationship. According to Grundtvig, the word is physical as well as spiritual because it is "the spirit's natural vehicle for expression" (Nielsen 1985, 50). The human word with human spirit derives from God's Word and Spirit with great creativity. Regin Prenter claims that Grundtvig's anthropology expresses the idea of human "essential equality with God," which in turn relates to the "original uniformity or homogeneity" (oprindelige ensartede) of God's Word and the human word (Prenter 1983a, 63). In his study of the relationship between God's Word and human words, Helge Grell states that incarnation makes the unity or "fusion of God's Word and the human word" (sammensmeltning mellem gudsordet og menneskeordet) a complete reality when God's Word can create things

${ }^{6}$ The English translations of Grundtvig's texts in this essay have been kindly corrected by Edward Broadbridge to whom I am very grateful. 


\section{WEN GE}

through human words in the power of the Holy Spirit (Grell 1980, 157). It even implies the protological fusion of God's Word and human words before the Fall. Because they are ontologically linked with God's Word, human words can express the invisible power of the spirit and human life that "clearly separates us from dumb animals" (US X, 500). Human words about spiritual truth correspond to God's living Word, and God bestows upon man the human life of faith, hope, and love to make possible a living divine-human interaction (Iversen 2010, 106-107).

This interactive life between the divine and the human also involves nature. In his interpretation of Grundtvig's theological anthropology, N.H. Gregersen involves not only the divine and the human, but also spirit and nature with humanity as the microcosmos that mediates the two (Gregersen 2002, 16). A human being is a microcosmos reflecting the interaction between spirit and nature and between the visible and the invisible. According to Gregersen, Grundtvig understands human beings in the traditional trichotomic way. He writes, for example, that the soul combines the essence of the spirit with the image of the body (Gregersen 2002, 14-15). This dynamic process, according to Gregersen, allows the realms of nature and of spirit to converge, making "a person [into] a microcosmos not only of the physical world, but also of the spiritual world" (Gregersen 2002, 16). Therefore, as human beings are linked with God, nature is also brought into the Trinitarian communion of love.

\section{The Influence of the Fall on the Deep Coinherent Relationship}

For Grundtvig, the word is the conveyer of the spirit, which is the power of life. Human words and spirits are derived from God's Word and Spirit, respectively. God's Word and human words are originally, freely corresponding to each other and becoming fused together in all expressions of truth. His "Mosaic-Christian anthropology" in 1832 informs us how he understands human life as God's creation:

For man is not an ape, destined first to ape the other animals and then himself until the world's end. Rather is he a glorious, incomparable creature, in whom divine powers through thousands of generations proclaim, develop and enlighten themselves as a divine experiment, in order 


\section{The Deep Coinherence}

to show how spirit and dust can permeate [or interpenetrate, giennemtrange] one another and be transfigured [or clarified] into a common divine consciousness. That is how man must be regarded if there is to be a spiritual learning on earth; and that is how man is regarded wherever the Jewish-Christian perception has been an inspiration $(S L, 66)$.

In this quotation Grundtvig apprises us of three most important things about human life. First of all, unlike animals, human beings have the creative spirit conveyed by the living words to transcend themselves and grow into the fullness of being God's children $(S l, 23)$. Secondly, a human being consists of inseparable dust and spirit. Thirdly, God creates human beings for the divine-human fellowship, which he regards as the divine destiny of human beings. Here, human words serve as the vehicle for human transcendence and divine-human communication.

The Fall, however, separates, to some extent, human words from God's Word and the human spirit from the Holy Spirit. Grundtvig writes that postlapsarian human words are "mixed with the words of lies and falsehood, which have created disbelief and sin among us" (HB III, 176). Thus human words cannot fully correspond to God's Word; consequently, human life becomes spiritually weak, powerless, or even dead.

Grundtvig understands the Fall as the moment humankind deviated from the life path towards becoming God's children $(S L, 22)$. As a result, human beings lost the spiritual vision and remained indulged in the worldly life. Original sin, in Grundtvig's thinking, happened when human beings lost the lofty aim of "the divine resemblance and the upward ascent" $(S L, 35)$ via the "spiritual ladder," but came to focus instead only on the world $(S L, 164)$, and they began making idols according to their sense, imagination, and inner divinity, which caused "corruption of life" with "perdition of death" $(S W, 78)$. Human life now is alive with "selflove, self-will, and self-conceit" [Egenkiarlighed, Selvraadighed og Selvklog$s k a b]$ which has not only "separated us from the old human life in the image of God, but also denied the new life in Christ Jesus" (US VIII, 443).

If we keep deep coinherence in mind, we see how the Fall also had a negative effect on nature. If human beings have lost their ability to see themselves as God's children, but have confined their vision to this worldly life, they can no longer properly mediate spirit and nature. Instead, they exploit nature. Grundtvig poetically describes the loss of coherence 


\section{WEN GE}

in a poetic way that the human fall results in "a divorce between heaven and earth as between spirit and flesh" (Quoted in Allchin 1997, 155). When human beings disregard their original divine destiny and preoccupy themselves with the world, they cannot mediate heaven and earth in the light of Christ's human life.

Grundtvig, however, believes that, despite the Fall the divine-human relationship, "God's given image is still alive" $(S W, 142)$ in human beings. People can still respond to God through human words out of their mouths, just as the Old Testament prophets interacted with God. Grundtvig does not believe that "there is nothing left of the created glory or the relation to God" after the Fall, for human words on their lips can still be the instruments to express God's spiritual truths ( $S W, 76)$. In the life of Christians, non-Christians, including Jews and Gentiles, a human life of faith, hope, and love is the external manifestation of imago Dei. The divine-human interaction therefore has not been suspended since the Fall.

Above all, living congregations preserve and bear witness to the special revelation of the Word. And human words in general can connect people to God, one another, and the world around them. This Grundtvigian solution must first be understood from the Christian and then from the human perspective, that is, first from the ministry of the redeeming Word in the living congregations and then from the ministry of the creative Word in the mouths of regular people. With the acknowledgement of the inseparability of the divine and the human, these two approaches are defined by Grundtvig as Christians' soteriological absorption into Christ to fulfill the human life and the naturalists' spiritual absorption of Christ into themselves to return to the original natural human life (SL, 61-62). The ministry of the Word both in Christian life with its incarnational effect in the church and in human life with His continuous creative effect on society and nation resembles what Regin Prenter calls "a Christology on two lines" (Prenter 1983a, 63).

\section{The Restoration from the Christian Perspective}

If the Fall made mankind forget how to recognize and respond to God's Word, then how can mankind be made to remember? Grundtvig's ecclesial perspective of 1825 offers a distinctive answer. Influenced by Ire- 


\section{The Deep Coinherence}

naeus, Grundtvig realizes the importance of the "oral tradition" of the Christian faith as the regula fidei for the universal Church (Thaning 1971, 42-44). He realizes that the apostles' words and writings constitute authentic Christianity, which is epitomized in the Symbolum Apostolicum (GDK I, 27, 32). This creed becomes the rule of faith and foundation of true Christianity, which Christians speak aloud to this day. ${ }^{7}$ So the Apostles' Creed at baptism becomes the living witness to God's Word of faith. Furthermore, according to Grundtvig, we hear clearly God's Word out of the Lord's own mouth in the Lord's Prayer and the institutional Word of sacraments in worship. Heard at baptism, the Lord's own living Word is enlivened by the Holy Spirit so that we can experience the transforming power of the Word. It is in living congregations that we clearly find God's Word again. We are called to respond to it through faith.

From the Christian perspective, uttering the Word starts the process of the restoration of the divine-human relationship. When proclaiming the Apostles' Creed, when reciting the Lord's Prayer, or when hearing the institutional Word of the sacraments, congregants respond to God's Word again. Christ's life and light are communicated through the fusion of human words and the divine Word. ${ }^{8}$ As a result, Christians are spiritually regenerated and renewed with the baptismal covenant. In this process, "The new human being is born and grows up in us in the same degree as God's living Word becomes quickened and clarified in our innermost being" (Quoted in GDKI, 132). This process enables the deep coinherence of the divine and the human within the Christian. Baptism marks the beginning of the Christian life to grow like Christ's earthly life. This life is but "a divine life in the order of human nature" (Quoted in GDKI, 186, 188).

7 Grundtvig draws his conclusion from his reflections in the text of "On True Christianity" (See: GDK I, 27, 32).

${ }^{8}$ Grundtvig claims that the institutional Word is also the Word of life and light as "our Lord Jesus Christ is both life and light in God's Kingdom, [who] is God the Father's only begotten Son and even a true Son of Man, and so certain as he is spiritually present with his congregation and works with and confirms our human word about Him with divine power." See Grundtvig, "Fra Vennemødet 1863," US X, 540. "The Lord's Word out of His mouth to us can communicate a life and a spirit to us," which we can only accept by faith, for "faith asks about what is true, trustworthy and salvific (saliggjørende), not about why it must be so, or how God's act is possible." (Ibid.) see also Grundtvig, Kirke-Spejl, US X, 85-6. 


\section{WEN GE}

Our confession of faith at baptism, our hope from praying the Lord's Prayer, and our love bestowed in the Holy Communion correspond to God's living Word to express this new life of faith. The Word of life and light, which "imparts and communicates a spirit and a life is spiritually present with His congregation and works with and confirms our human word about Him with God's power" (US X, 540).

Consequently, a group of Christians who share the common life of faith, hope, and love shapes a living congregation with Christian confession, proclamation, and praise as its external signs. Living congregations follow the archetype of the life of Christ; therefore, they bear witness to the kingdom of the Word here and now. ${ }^{9}$ Christianity is about a Christian human life that the human can "fuse together with the divine" (US X, 63). As in Christ Jesus, "The human and divine nature are reconciled and united, and the humanity of Christ grows up into the fullness of divinity in the Spirit of God" (US X, 97). Christ's life is the prototype of human life. Grundtvig declares this profound mystery when he writes,

The fusion of the divine and the human nature in Jesus Christ, and his mediator-role [Midler-Stilling], by which the perspective of all believers in Him is broadened to become as He is ... that is the great secret by which any others in comparison become small, the one that only in a mysterious way can become effective, of course, so that even with the most sober Christians its presence must never be questioned. For it is a valid, trustworthy warrant, as so much light in the darkness by which we guard ourselves against danger, and finally a blessed experience of the truth of the Gospel (US VIII, 449).

The Christ-life clearly demonstrates how divine and human life coinhere perfectly in the living Word through the Holy Spirit.

\footnotetext{
9 Prenter 1983, 22. Grundtvig regards "Christian life" as "Christ-life" so that Christians can have "real participation in Jesus Christ's own life." (Ibid.) See also Grundtvig, Kirkelige oplysninger (1840-42)," US VIII, 436. "Det Christelige Liv som et Christus-Liv." This also expresses the co-inherent relationship between Christ and Christians in the life characterized by faith, hope and love. (Ibid.)
} 


\section{The Deep Coinherence}

\section{The Restoration from the Human Perspective}

Despite the contamination of the human words as a result of the Fall, which may contain lies or falsehood, human words can still respond to God's Word to bring about a life of faith, hope, and love, albeit incomplete and fragmentary in naturalists' or heathens' lives. Grundtvig understands the heathen life as "what has been with people since ancient times and heathens consequently pertain to old, natural, pre-Christian human beings at each place" who can receive some "Christian blood in their veins" through baptism $(V U \mathrm{~V}, 393)$. Therefore, to restore the original divine-human relationship we must rely on the resurrection of the human words. Furthermore, according to Grundtvig, the natural human life always takes a concrete particular national form in the folkelig life (US IX, 86), which cannot be separated from the vernacular language, the spirit of the people, and the characteristics of the culture. He actually encouraged people to dare to become the original "heathens" again: "[L]et people grow up as heathens and let them fall back to heathenism" ( $V U \mathrm{~V}, 393)$. He meant that natural human life might be restored with free and living human words, which allow mankind to respond to God's continuously creative Word.

First of all, freedom is the basic condition for the spirit's as well as the word's work - a notion that Grundtvig seems to have embraced as a result of his three study trips to England between 1829-1831. His often-quoted opinion is that freedom should be extended to Loki as well as to Thor. Human words convey human spirits so they must be free to express the spirit's work and to voice people's opinions in public.

Grundtvig adamantly advocated freedom in Denmark because of his own experience with censorship, but it must be said, too, that he strongly opposed the kind of freedom only for oneself. He contended that the same freedom should also be simultaneously extended to one's neighbor (Henningsen 1980, 239). That is to say, Grundtvig understood that freedom must be relational and reciprocal, as "freedom of concurrence" happens in personal conscience as well as in political, ecclesial, and pedagogical life (Baagø 1955, 8). Gregersen points out that the word logos (Word) can be translated also "sermo (Sermon or Dialogue)" (Gregersen 2004, 26). Dialogue is the basic active form for both God's Word and human words; 


\section{WEN GE}

therefore, living dialogical interaction of individuals' words establishes a balanced democratic construction, and it revives natural human life.

Secondly, human words must be resurrected. His experience at the "black school" or "school for death" prompted Grundtvig to promote the living and spontaneous communication between people so that the spiritual power of life can be set free. At a level of national life, national languages, Danish in the case of Denmark, must be promoted to replace dominating foreign languages like German, Latin, or French that were prevalent especially amongst Danish elites and in Danish academic circles. The peasants especially needed to be trained in their mother tongue so that they could express themselves clearly at the Advisory Council. Grundtvig established the Danish people's high school where, instead of the traditional way of lecturing, he could highlight the interaction between teachers and students through living words. At the Roskilde Advisory meeting (1835-36) and through his lectures at Borchs Kollegium (1838), Grundtvig consolidated his supposition that the "great natural law for the work and propagation of the spirit" (Schrøder 1901, 123) has its roots in the secular resurrection of the living human words. Kristen Kold succinctly summarizes Grundtvig's plan for the schools with wordplay: the people's high school does not follow the traditional way of talking to students (tale til), but appeals (tiltale) to them (Schrøder 1901, 123). Steven Borish provides a discussion of the living word, which means primarily to oplive, "to fill with life, to make glad, to imbue with self-confidence, [and] to encourage." He explains that, secondly, the living word means to oplyse, "to teach to aspire to true enlightenment, [and] to want to serve the cause of life;" and finally, that the living word is to vakke, "to awaken" the sleeping spirit, the life force in human beings or in a nation (Borish 1996a, 13). This third connotation of the living word also has religious implications, especially in the Danish revival movements, where Borish suggests that it may even resemble "a sacrament" when heard in baptism and Holy Communion (Borish 1996b, 122).

When human words are set free and revived, the folkeliv can be transformed also. The free and living interaction between teachers and students, between the educated and uneducated, between students themselves, and between commoners and leaders enables people to network with and learn from each other, which breaks down the hierarchical barriers in the Danish nation $(S L, 276)$. The revival of national life is obviously an important 


\section{The Deep Coinherence}

mark of the restoration of the natural human life, which is prepared to have a living interaction with Christianity.

This must be attributed to the continuously creative ministry of the Word in the naturalists. By means of the secular resurrection of free, living words, naturalists unconsciously absorb Christ into themselves. Grundtvig is confident that the creative Word and the Spirit as Life-Giver will continue to work even in the non-Christians' life setting, though this is not easy to recognize due to the Fall. The continuous living interaction between God's Word and free and living human words covers all of life and shows "the deep coinherence" between the life of the individual, the nation, and the whole human race, thereby developing a way of thinking that is desirable for all social relations" (SL, 83-84). All this relies on the free and living nature of human words through which people can respond to God's Word as a basic preparation for conversion. This optimistic anthropological view enabled Grundtvig to bring forward his now well-known axiom "Human comes first, and Christian next" in the following poem. Here are the first and the last stanzas:

Human comes first, and Christian next!

for that is life's true order;

although called sheep, yet deem us not

mere beasts beyond all borders!

And evil into Christendom

can never even God transform:

Cast not to swine your jewels!

They who would truly human be while on this earth still living lending an ear to Truth's own word, to God the glory giving;

If Christian faith is the true way, though 'Christian' they be not today they will be so tomorrow!

(LW, 249-251) 


\section{WEN GE}

\section{The Restoration of Nature in the Deep Coinherent Relationship}

The restoration of the divine-human life in Grundtvig's theology also influences nature, transforming the God-Humanity-nature relationship. Human mediation of nature and spirit requires a driving force. According to Gregersen, that force is the overflowing grace from the eternal God of divine Providence, who, out of His surplus of love, extends His life to all His creatures including nature through the creative Word and the Spirit, and the Word and Spirit manifest the indwelling of God the Father in human beings (Gregersen 2002, 11-14). Consequently, according to the restored divine-human relationship from both Christian and human perspectives, human beings can naturally better mediate spirit and nature. Furthermore, as Gregersen points out, the true mediating microcomos is the Word as the true image of God, which manifests itself in the world through incarnation (Gregersen 2000, 85-89; 99). By observing Christ's life, we learn how perfectly His spirit, body and soul collaborate to engage nature. This is the Word or logos (reason or pattern) that Grundtvig expects to function in human logoi (words) (Gregersen 2004, 26). The English summary of Gregersen’s article translated by Børge Bendtsen renders this point as follows: "Christ is the archetypical microcosm, [and] humanity is the ectypal microcosm who, ideally at least, combines nature and spirit" (Bendtsen 2000, 218). Without nature, human salvation is not holistic but is degraded into a spiritual escape from the world. By not taking human sin against nature seriously, human beings have not treasured the costly grace manifested by the incarnate and crucified Word and extended to God's entire creation. Arthur Macdonald Allchin summarizes Grundtvig's view of human beings as follows: "Humanity...is to be understood cosmologically in relation to creation and theologically in relation to God" (Allchin 2000, 140). He adds that Grundtvig's theological anthropology does not separate spirit from flesh with the latter being part of nature as "God's creation," so that "the salvation, the transfiguration of the flesh of the believers, involves the salvation and transfiguration of the whole world" (Allchin 2000, 143). Thus those who lead a Christlike life shall regain the lofty aim of being God's children, and treat nature as Christ does. In this way, nature is also lifted again in the restored deep coinherent divine-human relationship. 


\section{The Deep Coinherence}

\section{Conclusion}

This essay has tried to explore how the concept of deep coinherence of the nature of the relationship between God and man can serve as the fundamental unifying structure of Grundtvig's theology. Grundtvig believed the Fall damaged that relationship but that Christ can restore it. It is the free and living interaction between God's Word and human words that underlies but also fulfills such a deep coinherent communion of God and His creation.

\section{Abbreviations}

GDKI-II Holger Begtrup, Grundtvigs Danske Kristendom I-II, Copenhagen, G. E. C. Gads Forlag, 1936.

HB I-III Haandbog i N.F.S. Grundtvigs Skrifter I-III, edited by Ernst J. Borup og Frederik Schrøder, Copenhagen, H. Hagerups Forlag, 1929-31.

LW Living Wellsprings: The Hymns, Songs, and Poems of N.FS. Grundtvig, translated Edward Broadbridge, edited by Edward Broadbridge and Uffe Jonas, Aarhus University Press, Aarhus 2015.

SL The School for Life: N. F. S. Grundtvig on Education for the People, translated by Edward Broadbridge, edited by Edward Broadbridge, Clay Warren and Uffe Jonas, Aarhus, Aarhus University Press, 2011.

US I-X Grundtvigs Udvalgte Skrifter I-X, edited by H. Begtrup, Copenhagen, Gyldendalske Boghandel-Nordisk Forlag, 1904-09.

VU I-X Verker i udvalg I-X, edited by G. Christensen and H. Koch. Copenhagen, Gyldendalske Boghandel-Nordisk Forlag, 1940-49.

\section{Bibliography}

Allchin, A. M. (2000), "The Holy Spirit in the Teaching of N.F.S. Grundtvig" in A. M. Allchin, S.A.J. Bradley, N.A. Hjelm, and J.H. Schjørring (ed.), Grundtvig in International Perspective: Studies in the Creativity of Interaction, Aarhus, Aarhus University Press, 135-146. 


\section{WEN GE}

- (1997), N. F. S. Grundtvig: An Introduction to his Life and Work, Aarhus, Aarhus University Press.

Borish, Steven M. (1996a), "The Concepts of 'Folkelighed' and the 'folkelig." in Folkevirke 51, no. 3, 12-15.

- (1996b), Danish Social Movements in a Time of Global Destabilization: Essays on the Heritage of Reventlow and Grundtvig, the Efterskole, the Postmodern, Vejle, Kroghs Forlag A/S.

Baagø, Kaj (1955), "Grundtvig og den Engelske liberalisme" in Grundtvig-Studier 1955, 7-37.

Gregersen, Niels Henrik (2000), "Mennesket som Mikrokosmos: Grundtvigs store digt om 'Menneske-Livet"' in Grundtvig-Studier 2000, 75-103.

- (2002), "Når der bliver mere ud af mindre: Grundtvigs menneskesyn" in Henrik Wigh-Poulsen, Hans Grishauge, Niels Jørgen Cappelørn, Joachim Garff og Henning Nielsen (ed.), Grundtvig-Kierkegaard: En samtale op høje tid, Copenhagen, Forlaget Vartov, 11-30.

- (2009), "Radical Generosity and the Flow of Grace" in Bo Kristian Holm and Peter Widmann (ed.), Word-Gift-Being: Justification-Economy-Ontology, Tübingen, Mohr Siebeck, 117-144.

- (2004), "Three Varieties of Pantheism." In Philip Clayton and Arthur Peacocke (ed.), In Whom We Live and Move and Have Our Being, Grand Rapids/ Michigan, Eerdmans, 19-35.

Grell, Helge (1980), Skaberordet og billedordet: Studier over Grundtvigs teologi om ordet, Copenhagen, Grundtvig-Selskabet.

Henningsen, Bern (1980), Politik eller Kaos?, Copenhagen, Berlingske Forlag.

Iversen, Hans Raun, (2010), Church Society and Mission: Twelve Danish Contributions to International Discussions, Copenhagen, Publikationer fra Det Teologiske Fakultet, Vol. 13.

Nielsen, Ernest D. (1985), What Constitutes Authentic Christianity, Philadelphia, Fortess.

Prenter, Regin (1983a) "Grundtvigs treenighedslære." I N.F.S. Grundtvig: theolog og kirkelare: predikener og foredrag fra 200-året, Sabro, 54-76.

- (1983b), Den Kirkelige Anskuelse: En indforelse i N.F.S. Grundtvigs folkelige og kristelige grundtanker, Christiansfeld, Forlaget Savanne.

Schrøder, Ludvig (1901), N.FS. Grundtvig, Copenhagen, Lehmann \& Stages Forlag.

Thaning, Kaj (1971), For Menneske-Livets Skyld: Grundtvigs opgør med sig selv, Copenhagen, Gyldendal. 


\section{The Deep Coinherence}

Wen, Ge (2013), The Deep Coinherence: A Chinese Appreciation of N.F.S. Grundtvig's Public Theology, PhD dissertation, Arts, Aarhus, Aarhus University,

\section{Internet Resources}

The Inklings: http://web.sbu.edu/friedsam/inklings/coinheretance.htm. (accessed January 3, 2013). 